\title{
Rapid propidium monoazide PCR assay for the exclusive detection of viable Enterobacteriaceae cells in pasteurized milk
}

\author{
T. Soejima, ${ }^{1}$ J. Minami, and K. Iwatsuki \\ Morinaga Milk Industry Co. Ltd., 5-1-83, Higashihara, Zama, Kanagawa 252-8583, Japan
}

\begin{abstract}
Pasteurized milk is a complex food and contains numerous PCR inhibitors and can often contain high levels of dead Enterobacteriaceae cells, depending on the condition of food sanitation. Usually, propidium monoazide (PMA) or ethidium monoazide PCR techniques decrease the number of dead bacteria by up to $3.5 \log$ to the associated dead bacteria with no treatment. However, this difference could be insufficient to completely inhibit DNA amplification in the PCR from $10^{6}$ cells of dead Enterobacteriaceae bacteria/mL, potentially contaminated in pasteurized milk. Actually, such potentially high levels of dead Enterobacteriaceae cells in milk has prevented milk researchers from applying PMA- or ethidium monoazide PCR to the assay of viable Enterobacteriaceae cells in milk. We, therefore, developed a rapid PMA real-time PCR whose minimum levels of detection were $1.5 \mathrm{log} \mathrm{cfu} / \mathrm{PCR}$ for Cronobacter muytjensii and Escherichia coli, and 2.5 $\log \mathrm{cfu} / \mathrm{PCR}$ for Salmonella enteritidis without DNA purification in milk matrices. The PMA real-time PCR allowed us to specifically detect viable Enterobacteriaceae cells $(5-10 \mathrm{cfu} / \mathrm{mL})$ in pasteurized milk $(20 \mathrm{~mL})$ within $7.5 \mathrm{~h}$ of total testing time, following the hygienic guidelines for pasteurized milk in the United States and European Union. The long DNA amplification (mainly $2,451 \mathrm{bp}$ ) of the 16S-23S rRNA gene was completely suppressed in highly contaminated dead Enterobacteriaceae cells (7.5 log cfu of Cronobacter muytjensii) in $20 \mathrm{~mL}$ of pasteurized milk by $23-\mu M$ PMA treatment. Although the contamination of the PCR reaction with $5 \%$ milk usually causes great inhibition, our method led to the successful elongation of PCR from viable Enterobacteriaceae cells still in the pasteurized milk matrices finally corresponding to 2 to $4 \mathrm{~mL}$ of milk PCR inhibitors without a DNA purification step. To comply with current customer demands for chilled
\end{abstract}

Received January 18, 2012.

Accepted March 18, 2012.

${ }^{1}$ Corresponding author: t_soezim@morinagamilk.co.jp pasteurized milk at the most excellent possible quality, our new technique could enable laboratory persons in a factory to conduct rapid milk coliform testing before shipping from a factory.

Key words: viable Enterobacteriaceae cells, pasteurized milk, propidium monoazide-PCR, real-time PCR

\section{INTRODUCTION}

In Japan, the total viable coliform counts (CC) in raw milk have been established to be 3 to $6 \log$ and 1 to $5 \log \mathrm{cfu} / \mathrm{mL}$ during the summer and fall months, respectively (Higoshi et al., 1977). However, to meet current consumer demands for chilled, fresh pasteurized milk that is of excellent quality, factories must ship the milk before the absence of viable CC has been confirmed. It is only immediately before its arrival at the supermarket that the potential CC are assessed. Indeed, PCR is a promising technique that may allow for the establishment of a rapid milk coliform test that could be conducted before shipping; however, DNA amplification must be suppressed in the potentially high number $(6 \log$ cells/mL) of dead coliform/Enterobacteriaceae bacteria that could be found in pasteurized milk.

The discrimination between viable and dead bacteria may be achieved using a propidium monoazide (PMA) or ethidium monoazide (EMA) treatment before conducting the PCR assay (Rudi et al., 2005b; Chang et al., 2009, 2010; Nocker and Camper, 2009; Soejima et al., 2009; Luo et al. 2010). These DNA-intercalating dyes permeate the membrane-compromised cells and covalently bind to chromosomal DNA, following irradiation with visible light. The covalent binding of EMA is also associated with DNA breakage (Soejima et al., 2007, 2008). Both PMA and EMA allow for the complete suppression of PCR from $10^{3}$ cells of dead bacteria/mL, but are likely to trigger false-positive results when over $10^{3}$ cells of dead bacteria/mL are present (Rudi et al., 2005a,b; Nocker et al., 2006). Thus, routine PMA-PCR or EMA-PCR would not be feasible for use with pasteurized milk that is contaminated with high numbers of dead coliforms/Enterobacteriaceae $\left(10^{6}\right.$ cells $\left./ \mathrm{mL}\right)$. 
We have recently reported that the degree of PCR suppression by EMA is mainly correlated with the length of the targeted DNA with the same gene (Soejima et al., 2011a). Additionally, it has been recently shown that PMA penetrates dead bacteria more selectively than EMA (Nocker et al., 2006). The measurement of viable $\mathrm{CC}$ has been widely replaced by the direct detection of Enterobacteriaceae bacteria to assess milk contamination in recent years. Consequently, we have developed a PMA real-time PCR assay that targets long Enterobacteriaceae specific DNA to evaluate milk quality.

\section{MATERIALS AND METHODS}

\section{Bacterial Culture and Preparation of Heat-Killed Cronobacter muytjensii}

Pure cultures of Cronobacter muytjensii ATCC 51329, Escherichia coli DH5a, Salmonella enterica serovar Enteritidis IID 604, Citrobacter koseri JCM 1658, Bacillus cereus JCM 2152, and Staphylococcus aureus ATCC 65388 were grown in brain heart infusion (BHI) broth (Eiken Chemical Co. Ltd., Tokyo, Japan). The broth medium was centrifuged at $3,000 \times g$ for $5 \mathrm{~min}$ at $4^{\circ} \mathrm{C}$, unless otherwise stated. The obtained pellet was resuspended and serially diluted in saline (Eiken Chemical Co. Ltd.) or commercial pasteurized milk that was purchased from a local grocery store (henceforth referred to as milk). Plate counts were performed in duplicate on SPC agar (Kanto Chemical Co. Inc., Tokyo, Japan) after incubation at $37^{\circ} \mathrm{C}$ for $18 \mathrm{~h}$ using serially diluted bacterial suspensions. To obtain heatkilled C. muytjensii, a saline cell suspension was boiled for $2 \mathrm{~min}$ and appropriately diluted.

\section{Linearity Between Cycle Threshold and Logarithmic Cell Number of Enterobacteriaceae Bacterial Suspensions as Assessed by Direct Real-Time Quantitative PCR Targeting 16S-23S Long DNA}

A $5-\mu \mathrm{L} \quad(0.1-6.9 \log \mathrm{cfu} / \mathrm{PCR})$ volume of each Enterobacteriaceae cell suspension ( $C$. muytjensii, E. coli, or Salmonella Enteritidis) was added to 50 $\mu \mathrm{L}$ of direct real-time quantitative PCR (DqPCR) master mix so as not to require a DNA isolation step (Soejima et al., 2011b), and $3 \mu \mathrm{L}$ of the forward primer (16S_2751F: 5'-CTACAATGGCGCATACAAAGAGAAGCGACCT-3') and reverse primer (23S_5201R: 5'-CTTCTCCCGAAGTTACGGCACCA-3') targeting Enterobacteriaceae sequences in an available kit form (G\&G Science Co. Ltd., Fukushima, Japan) was added at a final concentration of $0.6 \mu M$. The start and end sequences of the targeted DNA (16S-23S rRNA gene, principally 2,451 bp in length) for Enterobacteriaceae bacteria are shown in Figure 1. To obtain all DNA sequences as shown in Figure 1, the sequencing primers were independently designed at the upstream to the sequences of $16 \mathrm{~S}$ rRNA gene presented in Figure 1 and at the downstream to those of 23S rRNA gene disclosed in the same figure. Concretely, for a forward primer, the Seq_16S_2696F (5'-AAGGTGGGGATGACGTCAA-3'), targeting the conserved region in Enterobacteriaceae bacteria, B. cereus, and Staph. aureus was used. For reverse primers, the Seq_23S_Ent_23S_5279R (5'-TAAACAGTTGCAGCCAGCTGGTATCTTCGA-3'), Seq_BC_23S_5233 (5'-TATTCACTGCGGCTTTCCGTTAA-3'), and Seq_SA_23S_5238R (5'-TTCTCTCCGAAATAGCTTTAGGGCTAG-3')

were used for Enterobacteriaceae bacteria, B. cereus, and Staph. aureus. The PCR was performed using an iCycler iQ (Bio-Rad Laboratories Inc., Hercules, CA) as follows: 1 cycle at $94^{\circ} \mathrm{C}$ for $3 \mathrm{~min}, 40$ cycles at $94^{\circ} \mathrm{C}$ for $30 \mathrm{~s}, 60^{\circ} \mathrm{C}$ for $40 \mathrm{~s}$, and $68^{\circ} \mathrm{C}$ for $3 \mathrm{~min}$, followed by a final cycle at $95^{\circ} \mathrm{C}$ for $3 \mathrm{~min}$. Melting curves were obtained by heating the samples from 70 to $95^{\circ} \mathrm{C}$ in increments of $0.2^{\circ} \mathrm{C} / 10 \mathrm{~s}$. The PCR products were confirmed by gel electrophoresis on a $0.8 \%$ SeaKem GTG agarose (FMC BioProducts, Rockland, ME) gel made in $0.5 \times$ TAE buffer $(2.42 \mathrm{~g}$ of Tris/L, $0.57 \mathrm{~mL}$ of acetic acid/L, and $0.074 \mathrm{~g} / \mathrm{L}$ of $\mathrm{Na}_{2}$ EDTA), as previously described (Minami et al., 2010). For the negative control and specificity tests, $5 \mu \mathrm{L}$ of $\mathrm{SW}$ and the viable $B$. cereus (2.5-6.1 log cfu/PCR) and Staph. aureus (2.3-7.1 log $\mathrm{cfu} / \mathrm{mL}$ ) saline suspensions were each combined with the DqPCR master mix.

\section{Milk Treatment Followed by PMA Treatment}

First, the absence of an initial population of live Enterobacteriaceae cells in $1 \mathrm{~mL}$ of commercial milk with no artificially introduced bacteria was confirmed by coculturing SPC and Difco violet red bile agar (VRBA; Becton, Dickinson and Co., Sparks, MD) after growth at $37^{\circ} \mathrm{C}$ for $18 \mathrm{~h}$. After centrifugation $(3,000 \times g$ for 5 min at $25^{\circ} \mathrm{C}$ ) of $20 \mathrm{~mL}$ of the aforementioned commercial milk, the pellet was resuspended in $10 \mathrm{~mL}$ of BHI broth that was supplemented with $25 \mu \mathrm{L}$ of proteinase K (Sigma, St. Louis, MO) solution $(25 \mathrm{U} / \mathrm{mL})$. Subsequently, the suspension was incubated in a Personal 11 water bath shaker (Taitec Corp., Tokyo, Japan) at 169 rpm for $3 \mathrm{~h}$ at $37^{\circ} \mathrm{C}$ to simultaneously allow for target bacterial growth and the decomposition of PCR inhibitors, such as micellar casein. After centrifugation $(3,000$ $\times g$ for 5 min at $25^{\circ} \mathrm{C}$ ), the pellet was resuspended in $1 \mathrm{~mL}$ of saline and transferred to a $1.5-\mathrm{mL}$ microtube. 


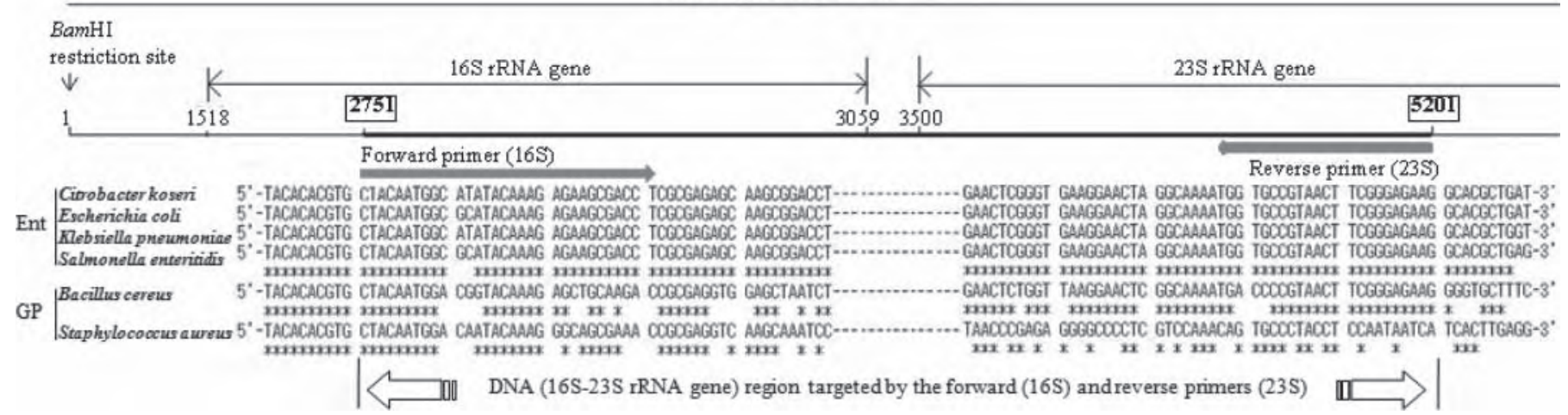

Figure 1. Start and end sequences of the gene region set with the forward (16S_2751F) and reverse (23S 5201R) primers: comparison of the $16 \mathrm{~S}$ and 23S rRNA genes from Enterobacteriaceae and gram-positive bacteria (Bacillus cereus and Staphylococcus aureus). The aforementioned primer pair principally amplified 2,451 bp DNA fragments to be targeted. The absence of an asterisk denotes differences in the amplified DNA sequences. Ent $=$ Enterobacteriaceae bacteria; $\mathrm{GP}=$ gram-positive bacteria.

For the viability tests before and after the proteinase $\mathrm{K}$ treatment, the 1-mL aliquot was cocultured with SPC and VRBA. A filter-sterilized solution of $1,000 \mu \mathrm{g} /$ mL of PMA (Biotium Inc., Hayward, CA) in deionized water was stored at $-20^{\circ} \mathrm{C}$ in the dark until use. Then, either $12.14 \mu \mathrm{L}$ of the PMA solution $(23.5 \mu \mathrm{M}$ final concentration) or the same volume of sterilized water (SW) was added. The PMA treatment time (10 min) and irradiation ( $5 \mathrm{~min}$ ) by visible light were performed as described previously (Minami et al., 2010). After centrifugation $\left(3,000 \times g\right.$ for $5 \mathrm{~min}$ at $\left.25^{\circ} \mathrm{C}\right)$, the pellet was resuspended in $1 \mathrm{~mL}$ of SW. One-milliliter aliquots that were diluted 5 and 10 fold in SW were prepared (milk components corresponding to 4 and $2 \mathrm{~mL}$ of milk), centrifuged, resuspended in SW to a final volume of $5 \mu \mathrm{L}$, and added to $50 \mu \mathrm{L}$ of the DqPCR master mix (Soejima et al., 2011b). The PCR was performed as previously mentioned in this paper. When the milk components corresponding to 4- or 2-mL milk were contaminated in the DqPCR master mix, we defined them in $4 \times$ or $2 \times$ milk matrices in later-mentioned Tables 1 to 3 , respectively.

Commercial milk samples (control milk that contained an undetectable number of viable Enterobacteriaceae cells due to coculture with SPC and VRBA agar) were single-strain spiked with viable Enterobacteriaceae cells (Table 2). The inoculation levels (mean $\pm \mathrm{SD}$ ) ranged from $1.8 \pm 0.0$ to $2.4 \pm 0.0 \log \mathrm{cfu} / 20 \mathrm{~mL}$ of milk for $C$. muytjensii, E. coli, and Salmonella Enteritidis, taking into consideration the detection limit $(5-10 \mathrm{cfu} / \mathrm{mL})$ of viable coliform cells, following the pasteurized milk guidelines from the United States and European Union (Hillerton and Elizabeth, 2004; McLaughlin, 2006). Hereinafter, the experimental procedures followed the above-mentioned milk treatment, followed by PMA treatment.

\section{RESULTS}

\section{Standard Curves Obtained From DqPCR Using Enterobacteriaceae Cells That Were Suspended in Sterile Water}

For the specificity of our DqPCR assay, it revealed all negative results for the negative control (using SW) and the viable B. cereus and Staph. aureus suspensions. Furthermore, as presented in Figure 1, the elongated gene sequences significantly differed between the Enterobacteriaceae and gram-positive bacteria in our assay.

The range of linearity seemed to be strain dependent (Figure 2). For C. muytjensii, E. coli, and Salmonella Enteritidis, linearities were obtained in ranges of 2.9 to 6.0, 0.9 to 5.0, and 2.9 to $6.0 \log \mathrm{cfu} / \mathrm{PCR}$. The squares of the correlation coefficients were $0.998,0.985$, and 0.963 for C. muytjensii, E. coli, and Salmonella Enteritidis, respectively. Concentrations exceeding $6.9 \log \mathrm{cfu} /$ PCR led to the failed detection of the target bacteria due to the large quantity of bacterial cell debris.

\section{Cycle Threshold Versus Logarithmic Cell Number for Enterobacteriaceae Bacteria That Were Resuspended in PMA-Treated Milk Matrices With No Artificially Introduced Bacteria}

Compared with the cycle threshold $(\mathrm{Ct})$ values that were observed in the Enterobacteriaceae cells suspended in SW, cells that were freshly suspended in a matrix of $2 \times$ PMA-treated milk pellets (matrices) that had been procured from the procedures described above (using 20 $\mathrm{mL}$ of milk with no artificially introduced bacteria with a low dose of proteinase $\mathrm{K}$ treatment in BHI medium followed by PMA treatment, and 10-fold dilution of 
Table 1. Cycle threshold $(\mathrm{Ct})$ versus logarithmic cell number for Enterobacteriaceae bacteria that were resuspended in propidium monoazide $(\mathrm{PMA})^{1}$-treated milk matrices

\begin{tabular}{|c|c|c|c|c|c|c|}
\hline \multirow[b]{2}{*}{ Culture } & \multicolumn{6}{|c|}{ Log cfu/PCR } \\
\hline & $5.5 \pm 0.1$ & $4.5 \pm 0.1$ & $3.5 \pm 0.1$ & $2.5 \pm 0.1$ & $1.5 \pm 0.1$ & 0 \\
\hline \multicolumn{7}{|c|}{ Cronobacter muytjensii ATCC $51329^{2}$} \\
\hline \multicolumn{7}{|c|}{ In milk matrices $(2 \times)^{3}$} \\
\hline Ct value & $20.6 \pm 0.2^{4}$ & $24.1 \pm 0.3$ & $27.6 \pm 0.8$ & $30.7 \pm 1.0$ & $33.4, \mathrm{ND}^{5}$ & $\mathrm{ND} \times 2$ \\
\hline $\operatorname{Tm}(\mathrm{Ps}, \mathrm{Pt})^{6}$ & $(87.2,88.2), 2 / 2^{7}$ & $(87.2,88.3), 2 / 2$ & $(87.1,88.3), 2 / 2$ & $(87.2,88.4), 2 / 2$ & $(87.2,88.3), 1 / 2$ & $0 / 2$ \\
\hline Gel electrophoresis & $2 / 2^{7}$ & $2 / 2$ & $2 / 2$ & $2 / 2$ & $1 / 2$ & $0 / 2$ \\
\hline $\operatorname{Tm}(\mathrm{Ps}, \mathrm{Pt})$ & $(87.2,88.3), 2 / 2$ & $(87.2,88.3), 2 / 2$ & $(87.2,88.4), 2 / 2$ & $(87.1,88.3), 2 / 2$ & $(87.2,88.3), 1 / 2$ & $0 / 2$ \\
\hline Gel electrophoresis & $2 / 2$ & $2 / 2$ & $2 / 2$ & $2 / 2$ & $1 / 2$ & $0 / 2$ \\
\hline \multicolumn{7}{|l|}{ Escherichia coli $\mathrm{DH} 5 \alpha$} \\
\hline \multicolumn{7}{|l|}{ In milk matrices $(2 \times)$} \\
\hline Ct value & $20.2 \pm 0.2$ & $22.0 \pm 0.4$ & $24.8 \pm 0.7$ & $28.4 \pm 1.0$ & $31.6 \pm 1.0$ & $\mathrm{ND} \times 2$ \\
\hline $\operatorname{Tm}(\mathrm{Ps}, \mathrm{Pt})$ & $(86.8,88.0), 2 / 2$ & $(86.8,88.0), 2 / 2$ & $(86.8,88.1), 2 / 2$ & $(86.7,88.0), 2 / 2$ & $(86.7,87.9), 2 / 2$ & $0 / 2$ \\
\hline Gel electrophoresis & $2 / 2$ & $2 / 2$ & $2 / 2$ & $2 / 2$ & $2 / 2$ & $0 / 2$ \\
\hline \multicolumn{7}{|c|}{ In milk matrices $(2 \times)$} \\
\hline Ct value & $20.9 \pm 0.4$ & $23.3 \pm 0.6$ & $28.8 \pm 0.7$ & $31.6 \pm 1.0$ & $\mathrm{ND} \times 2$ & $\mathrm{ND} \times 2$ \\
\hline Tm (Ps, Pt) & $(87.0,88.2), 2 / 2$ & $(87.0,88.2), 2 / 2$ & $(86.9,88.1), 2 / 2$ & $(86.8,88.0), 2 / 2$ & $\mathrm{ND}, 0 / 2$ & $0 / 2$ \\
\hline Gel electrophoresis & $2 / 2$ & $2 / 2$ & $2 / 2$ & $2 / 2$ & $\mathrm{ND}, 0 / 2$ & $0 / 2$ \\
\hline \multicolumn{7}{|l|}{ In sterile water } \\
\hline Ct value & $18.8 \pm 0.3$ & $21.2 \pm 0.6$ & $26.3 \pm 0.8$ & $28.9 \pm 1.2$ & $\mathrm{ND} \times 2$ & $\mathrm{ND} \times 2$ \\
\hline $\operatorname{Tm}(\mathrm{Ps}, \mathrm{Pt})$ & $(87.0,88.2), 2 / 2$ & $(87.0,88.2), 2 / 2$ & $(87.0,88.1), 2 / 2$ & $(86.9,88.1), 2 / 2$ & $\mathrm{ND}, 0 / 2$ & $0 / 2$ \\
\hline Gel electrophoresis & $2 / 2$ & $2 / 2$ & $2 / 2$ & $2 / 2$ & $\mathrm{ND}, 0 / 2$ & $0 / 2$ \\
\hline
\end{tabular}

${ }^{1}$ Biotium Inc., Hayward, CA.

${ }^{2} \mathrm{ATCC}=$ American Type Culture Collection, Rockville, MD.

${ }^{3} \mathrm{~A}$ 20-mL aliquot of pasteurized milk was treated with PMA after a 3-h pre-enrichment with a low concentration of proteinase K. Following centrifugation, 1/10 amounts of milk pellets were collected in a PCR tube $(2 \times$ milk matrices corresponding to pellet originating from $2 \mathrm{~mL}$ of milk) and the targeted bacterial inoculation was subsequently performed.

${ }^{4}$ The direct real-time quantitative PCR (DqPCR) measurements were performed in duplicate, and the Ct values are represented as the mean $\pm \mathrm{SD}$.

${ }^{5} \mathrm{ND}=$ not detectable.

${ }^{6} \mathrm{Tm}(\mathrm{Ps}, \mathrm{Pt})=$ the melting point analysis in duplicate. Ps indicates a peak shoulder and Pt indicates a peak.

${ }^{7} \mathrm{i} / 2$ ( $\mathrm{i}=0$ to 2 ) represents the number of positive results per duplicate measurements.

${ }^{8} \mathrm{IID}=$ Institute of Medical Science, University of Tokyo, Tokyo, Japan.

test samples) showed higher values. The experimental results suggest that some of the components in the milk still possessed PCR-inhibitory effects (Table 1). Additionally, concentrations exceeding $1.5 \log \mathrm{cfu} / \mathrm{PCR}$ of Enterobacteriaceae cells were necessary for the DqPCR assay to effectively assess the targeted cells.

\section{Detection of Viable Enterobacteriaceae Cells Artificially Inoculated in Pasteurized Milk Using the PMA-DqPCR Assay, Melting Point Analysis, and Gel Electrophoresis}

The low dose of proteinase $\mathrm{K}$ pretreatment at $37^{\circ} \mathrm{C}$ for $3 \mathrm{~h}$ in $\mathrm{BHI}$ broth caused the targeted viable cells (mean $\pm \mathrm{SD}$ ) to increase by at least 1 log unit to concentrations ranging from $3.0 \pm 0.0$ to $4.1 \pm 0.1 \mathrm{log} \mathrm{cfu} / \mathrm{sample}$
(Table 2). Simultaneously, the sizes of the sample pellets markedly decreased due to the decomposition of milk proteins, such as micellar casein. As shown in Table 2, the control milk yielded no viable Enterobacteriaceae cells either before or after the short 3-h incubation, indicating the lack of growth of the resuscitated cells. The PMA-DqPCR targeting the 16S-23S rRNA gene led to the successful suppression of PCR amplification in the heat-killed C. muytjensii $(7.5 \mathrm{log}$ cfu/20 $\mathrm{mL}$ of control milk in Table 2) because at least 1 molecule of PMA may have cross-linked to the very long 2,451 bp DNA (Soejima et al., 2011a). This PMA-DqPCR assay for pasteurized milk involves targeted bacterial growth and the simultaneous decomposition of PCR inhibitors in the milk $(3 \mathrm{~h})$, a series of PMA treatments $(1 \mathrm{~h})$, and DqPCR $(3.5 \mathrm{~h})$. 
Table 2. Detection of viable Enterobacteriaceae cells artificially inoculated in pasteurized milk using the propidium monoazide $(\mathrm{PMA})^{1}$ direct real-time quantitative PCR (DqPCR) assay, melting point (Tm) analysis, and gel electrophoresis

\begin{tabular}{|c|c|c|c|c|c|c|}
\hline Culture & $\begin{array}{l}\text { PMA } \\
\text { treatment }\end{array}$ & $\begin{array}{c}\begin{array}{c}\text { Before } \\
\text { incubation }\end{array} \\
\begin{array}{c}\text { Log cfu/s } \\
\text { sample }^{3}\end{array}\end{array}$ & $\begin{array}{c}\begin{array}{c}\text { After } \\
\text { incubation } \\
(3 \mathrm{~h})\end{array} \\
\begin{array}{c}\text { Log cfu/ } \\
\text { sample }^{3}\end{array}\end{array}$ & \multicolumn{3}{|c|}{ DqPCR $(2 \times \text { milk matrices })^{2}$} \\
\hline \multirow{2}{*}{ Cronobacter muytjensii ATCC51329 $9^{4}$} & $+^{5}$ & $1.8 \pm 0.03$ & $3.7 \pm 0.23$ & $28.5 \pm 0.92$ & $2 / 2(\operatorname{Ps} 87.2, \text { Pt } 88.3)^{6}$ & $2 / 2^{7}$ \\
\hline & + & $2.1 \pm 0.03$ & $3.9 \pm 0.20$ & $27.8 \pm 0.67$ & $2 / 2(\mathrm{Ps} 87.2, \mathrm{Pt} 88.3)$ & $2 / 2$ \\
\hline \multirow[t]{2}{*}{ Salmonella Enteritidis IID $604^{8}$} & + & $2.1 \pm 0.05$ & $4.0 \pm 0.05$ & $29.0 \pm 0.78$ & $2 / 2(\operatorname{Ps} 87.0, \mathrm{Pt} 88.2)$ & $2 / 2$ \\
\hline & + & $2.4 \pm 0.05$ & $4.1 \pm 0.09$ & $28.9 \pm 0.47$ & $2 / 2(\operatorname{Ps} 87.0, \mathrm{Pt} 88.3)$ & $2 / 2$ \\
\hline \multirow{2}{*}{ Control milk ${ }^{9}$} & + & $\mathrm{ND}^{10}$ & ND & ND & $0 / 2$ & $0 / 2$ \\
\hline & $-{ }^{5}$ & ND & ND & $24.8 \pm 0.55$ & $2 / 2(\operatorname{Ps} 87.2, \mathrm{Pt} 88.1)$ & $2 / 2$ \\
\hline Control milk inoculated with heat-killed & + & ND & ND & ND & $0 / 2$ & $0 / 2$ \\
\hline $\begin{array}{l}\text { C. muytjensii ATCC } 51329 \\
(7.5 \pm 0.06 \log \mathrm{cfu} / \mathrm{sample})\end{array}$ & - & ND & ND & $19.2 \pm 0.43$ & $2 / 2(\operatorname{Ps} 87.2$, Pt 88.3$)$ & $2 / 2$ \\
\hline
\end{tabular}

${ }^{1}$ Biotium Inc., Hayward, CA.

${ }^{2}$ The $2 \times$ milk matrices corresponded to $1 / 10$ amounts of pellets obtained from centrifugation of $20 \mathrm{~mL}$ of milk (following 3-h incubation and PMA treatment), which were added to a PCR tube, and then DqPCR was performed in duplicate.

${ }^{3}$ Targeted viable cell count per $20 \mathrm{~mL}$ of milk using the culture method.

${ }^{4} \mathrm{ATCC}=$ American Type Culture Collection, Rockville, MD.

${ }^{5}$ The + and - represent PMA treatment and no PMA treatment, respectively.

${ }^{6}$ Detection by Tm analysis (number of positive results per 2 replicates); Ps indicates a peak shoulder and Pt indicates a peak.

${ }^{7}$ Detection by gel electrophoresis (number of positive results per 2 replicates).

${ }^{8} \mathrm{IID}=$ Institute of Medical Science, University of Tokyo, Tokyo, Japan.

${ }^{9} \mathrm{Control} \mathrm{milk} \mathrm{is} \mathrm{the} \mathrm{commercial} \mathrm{milk} \mathrm{with} \mathrm{no} \mathrm{artificially} \mathrm{inoculated} \mathrm{bacteria.}$

${ }^{10} \mathrm{ND}=$ not detectable.

\section{Detection of Enterobacteriaceae Cells in the Commercial Pasteurized Milk With No Artificially Inoculated Bacteria Using DqPCR With or Without PMA Treatment}

Instead of an internal positive control (as a positive control for each commercial pasteurized milk), to $2 \times$ and $4 \times$ milk matrices originating from each commercial pasteurized milk with no artificially introduced bacteria with or without PMA treatment in the PCR tube, the viable C. muytjensii (5.5 log cfu/PCR) was newly added, and then the $\mathrm{Ct}$ values were obtained, ranging from 18.9 to 22.6 in all positive controls. Next, the DqPCR data from the $2 \times$ and $4 \times$ milk matrices that were not treated with PMA (Table 3 ) revealed that 9 out of 11 tested samples developed Enterobacteriaceaepositive results in the former, whereas only 5 out of 11 became positive in the latter. The $4 \times$ milk matrices had a greater inhibitory effect on the DqPCR assay compared with the $2 \times$ milk matrices; thus, we mainly used the data from the $2 \times$ milk matrices to evaluate the correlation between the DqPCR without PMA, PMADqPCR, and culture method. Regardless of the milk sample, the PMA-DqPCR assay $(2 \times$ milk matrices $)$ was never detectable for viable Enterobacteriaceae cells and was strongly correlated with the culture method.
However, a significant difference $(P<0.01 ; \Phi=1)$ was found between DqPCR without PMA and the culture method due to the McNemar test, which was performed using SPSS version 10.0 software (SPSS Inc., Chicago, IL), using a total of 22 measurement data obtained from 11 milk samples. The DqPCR without PMA was not correlated to the culture method.

\section{DISCUSSION}

Polymerase chain reaction assays have previously been applied in microbiological milk analyses that involve preliminary enrichment for 4 to $16 \mathrm{~h}$ (Cooray et al., 1994; Kim et al., 2001; Meiri-Bendek et al., 2002; Pillai and Jayarao, 2002; Fode-Vaughan et al., 2003; Wu and Kado, 2004; Cai et al., 2005). The PCR protocol to detect mastitis in bovine milk directly without pre-enrichment has been reported (Cressier and Bissonnette, 2011). In addition, a PCR method for assay of lactosefermenting Enterobacteriaceae bacteria in the dairy food industries has already been developed (Martín et al., 2010). However, the robust discrimination method between viable and dead Enterobacteriaceae cells in pasteurized milk by PCR has not yet been reported, putting into consideration a routine test following the later-mentioned United States and European Union 
Table 3. Detection of Enterobacteriaceae cells in the commercial pasteurized milk with no artificially inoculated bacteria using direct real-time quantitative PCR (DqPCR) with or without propidium monoazide (PMA) ${ }^{1}$ treatment

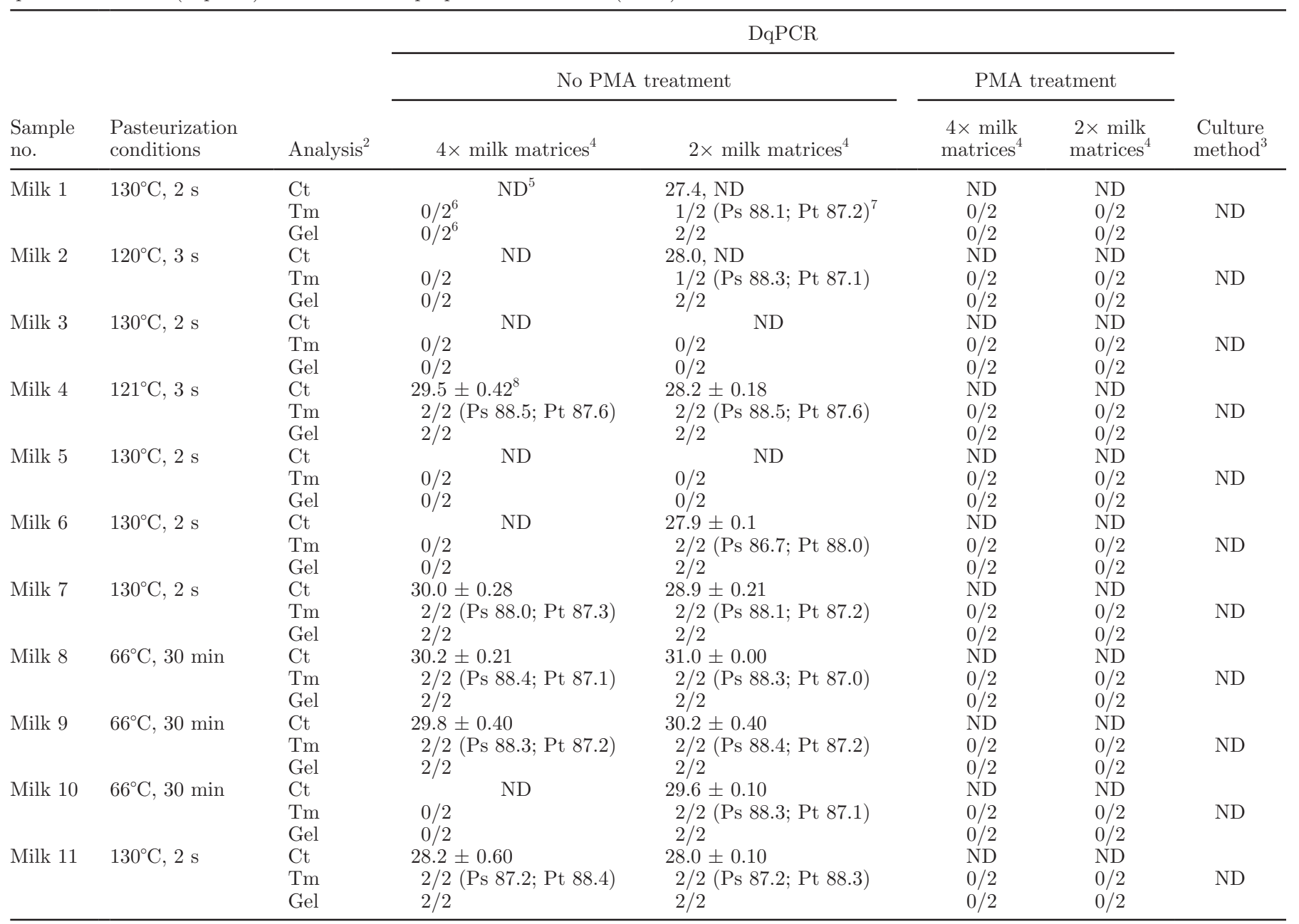

${ }^{1}$ Biotium Inc., Hayward, CA.

${ }^{2} \mathrm{Ct}=$ cycle threshold; $\mathrm{Tm}=$ melting point analysis; $\mathrm{Gel}=$ gel electrophoresis.

${ }^{3}$ Standard plate count (SPC) agar (Kanto Chemical Co. Inc., Tokyo, Japan) and Difco violet red bile agar (VRBA; Becton, Dickinson and Co., Sparks, MD) were used for coculturing and detecting the general and Enterobacteriaceae bacteria in $1 \mathrm{~mL}$ of pasteurized milk.

${ }^{4}$ The $2 \times$ or $4 \times$ milk matrices correspond to $1 / 10$ or $1 / 5$ amounts of pellets obtained after the centrifugation of $20 \mathrm{~mL}$ of pasteurized milk treated with proteinase K, followed by no PMA or PMA treatment before PCR. As a positive control for each commercial pasteurized milk, the viable Cronobacter muytjensii (5.5 $\log \mathrm{cfu} / \mathrm{PCR})$ was newly added to each $2 \times$ and $4 \times$ milk matrix with or without PMA treatment in a PCR tube to confirm Ct values of all positive controls ranging from 18.9 to 22.6 .

${ }^{5} \mathrm{ND}=$ not detectable.

${ }^{6} \mathrm{i} / 2$ (i = 0 to 2 ) represents a positive number (i) per 2 duplicates that were obtained from the Tm or gel electrophoresis of the DqPCR products. ${ }^{7} \mathrm{Ps}$ indicates a peak shoulder of the Tm analysis, and Pt indicates a peak of the Tm analysis.

${ }^{8} \mathrm{Ct}$ values by $\mathrm{DqPCR}$ are represented as mean $\pm \mathrm{SD}(\mathrm{n}=2)$.

milk guidelines. The hygienic guidelines for pasteurized milk in the United States and European Union require that $\mathrm{CC}$ do not exceed 10 and $5 \mathrm{cfu} / \mathrm{mL}$, respectively (Hillerton and Elizabeth, 2004; McLaughlin, 2006); therefore, in the present study, a 20-mL aliquot of milk to meet the sever criteria, which was either uninoculated or inoculated with viable or heat-killed Enterobacteriaceae cells (single-strain), was prepared for the harvest of viable Enterobacteriaceae cells at the highest possible number. Polymerase chain reaction fails if the final concentration of milk in the $\mathrm{PCR}$ reaction mixture is higher than 5\% (Bickley et al., 1996). However, we demonstrate specific detection of viable Enterobacteriaceae cells in pasteurized milk by DqPCR to target long DNA (16S-23S: mainly 2,451 bp) following PMA treatment even in the milk matrices corresponding to $2 \mathrm{~mL}$ of milk using $20 \mathrm{~mL}$ of milk of a great volume to harvest the target bacteria at the highest possible cells 


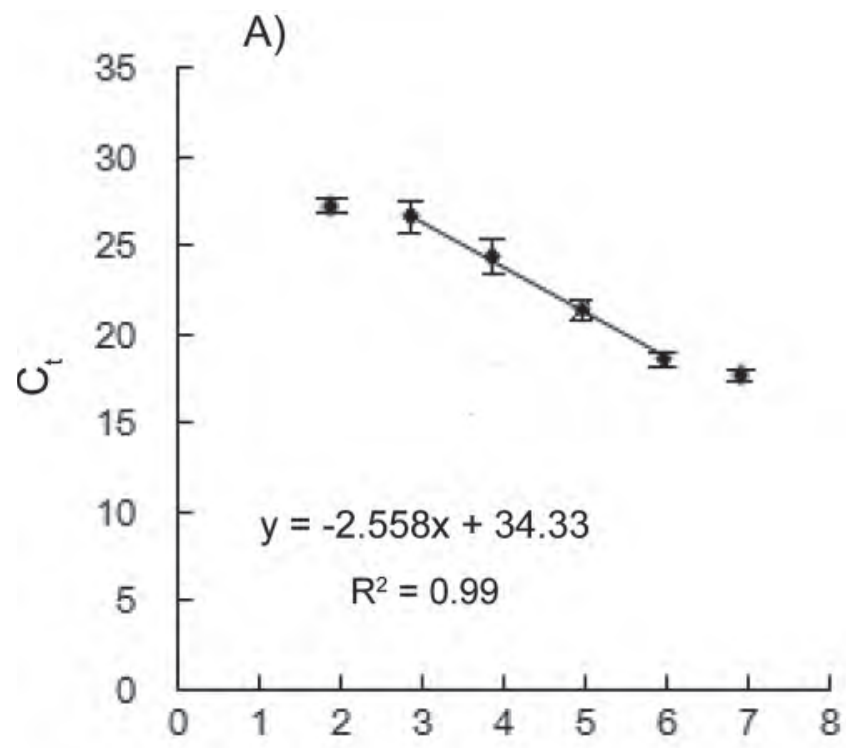

C)

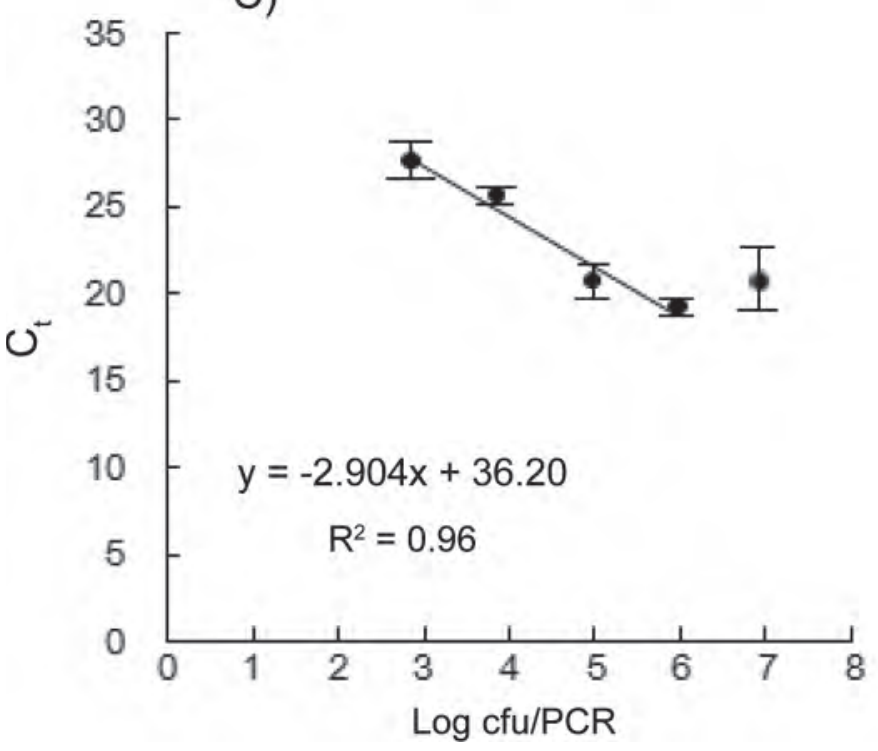

B)

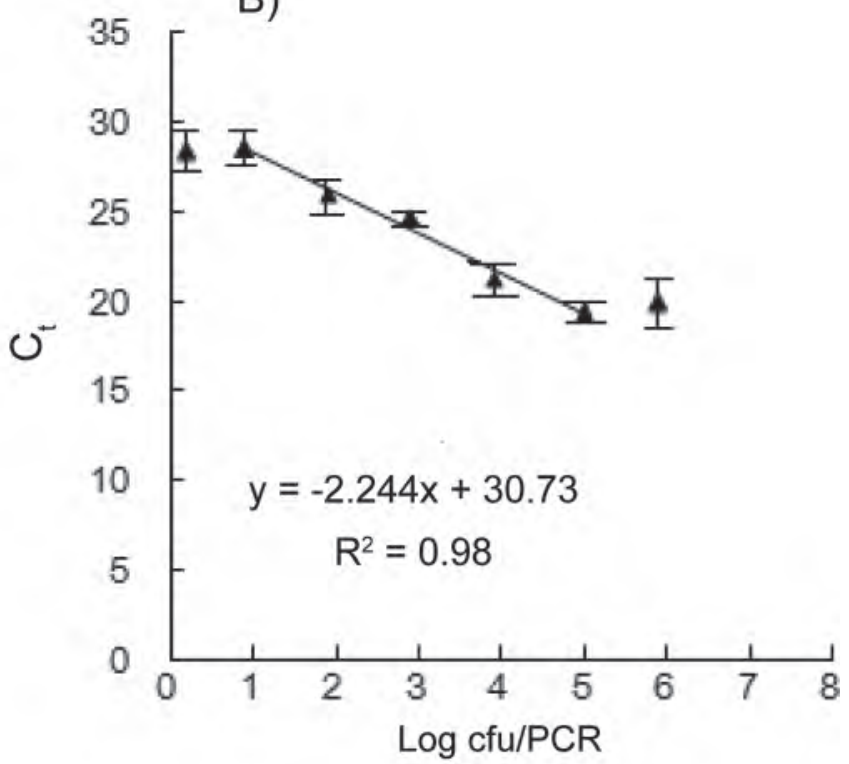

Figure 2. Standard curves obtained from direct real-time quantitative PCR (DqPCR) using Enterobacteriaceae cells that were suspended in sterile water. A) Cronobacter muytjensii ATCC 51329, B) Escherichia coli DH5 linearity (square of correlation coefficient: $R^{2}$ ) between the logarithmic number of cells and the cycle threshold $\left(\mathrm{C}_{t}\right)$ values presented with the regression line. The DqPCR measurements were performed in 4 replicates at each logarithmic cell number, and $\mathrm{C}_{\mathrm{t}}$ data are presented as the

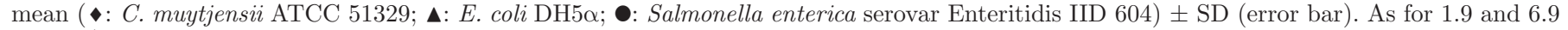
$\log \mathrm{cfu} / \mathrm{PCR}$ of $C$. muytjensii, the $\mathrm{C}_{\mathrm{t}}$ data obtained from 3 replicates were plotted owing to the nonamplification of 1 out of 4 measurements.

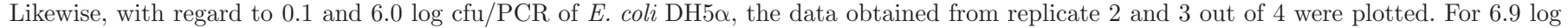
$\mathrm{cfu} / \mathrm{PCR}$ of Salmonella enterica serovar Enteritidis, the data obtained from 3 out of 4 replicates were plotted on the graph of $\mathrm{C}_{\mathrm{t}}(\mathrm{y}$-axis) versus logarithmic cell number. ATCC = American Type Culture Collection, Rockville, Maryland; IID = Institute of Medical Science, University of Tokyo, Tokyo, Japan.

number considering PCR inhibition. This is the first study to successfully perform PCR under strong PCR inhibitors of great milk volumes.

To meet customer demands for the highest quality chilled pasteurized milk in the freshest possible condition, factories must ship the pasteurized milk for pro- ducing dairy products before they have confirmed the absence of viable Enterobacteriaceae bacteria. It is only immediately before its arrival at the supermarket that the potential viable Enterobacteriaceae bacteria are assessed. We should develop a promising methodology that would allow rapid milk Enterobacteriaceae testing 
in a dairy laboratory of the processor to be conducted before shipping from a factory. Therefore, our established rapid technique may introduce the innovation for the safe distribution of chilled milk in the freshest possible condition.

Compared with EMA, PMA appeared to be highly selective in penetration into only dead bacteria with a compromised cell membrane, but not viable bacteria with an intact cell membrane and cell walls (Nocker et al., 2006). So, apart from EMA-PCR, we also report the use of PMA-DqPCR to assess commercial pasteurized milk with no artificially introduced bacteria, focusing on viable Enterobacteriaceae cells, as shown in Table 3. No viable Enterobacteriaceae cells were detected in any of the 11 commercial pasteurized milk cultures (due to coculturing with SPC and VRBA agars), as was expected for samples of Japanese origin. The 20 additional samples of pasteurized milk that were assessed also showed no targeted viable cells by the culture method (data not shown). As it is not easy for us to obtain coliform/Enterobacteriaceae-positive samples in commercialized pasteurized milks with no artificially inoculated bacteria in Japan, we exogenously added the viable Enterobacteriaceae cells to the commercial pasteurized milk (Table 2). However, in Japan, if once the presence of viable coliform/Enterobacteriaceae is detected in pasteurized milk, it will be a critical matter in view of the regulation of food hygiene.

The $\mathrm{CC}$ in raw milk range from 1 to $6 \log \mathrm{cfu} / \mathrm{mL}$ throughout all of the seasons in Japan (Higoshi et al., 1977). It appears that our PMA-DqPCR assay, which targets long $16 \mathrm{~S}$ to $23 \mathrm{~S}$ DNA sequences, seems to completely suppress the PCR from dead (heat-killed) Enterobacteriaceae cells that potentially contaminate pasteurized milk (control milk with PMA treatment in Tables 2 and 3). Actually, our methodology completely inhibits the PCR amplification from the artificially introduced heat-killed C. muytjensii (7.5 log cfu/20 mL milk; Table 2).

A low dose of proteinase $\mathrm{K}$ treatment in BHI broth at $37^{\circ} \mathrm{C}$ for $3 \mathrm{~h}$ allows the increasing cell number of viable Enterobacteriaceae bacteria exogenously added by 1 to $2 \log$ cfu/sample and simultaneous decomposition of potent PCR inhibitors such as micellar casein originating from $20 \mathrm{~mL}$ of milk (Table 2). This low dose of proteinase $\mathrm{K}$ treatment may accelerate PCR to be introduced into dairy milk analysis because a large milk volume can be targeted.

\section{CONCLUSIONS}

Our PMA-DqPCR assay targeting a long DNA sequence (16S-23S rRNA gene) enabled us to successfully and specifically detect low numbers $(5-10 \mathrm{cfu} / \mathrm{mL})$ of viable Enterobacteriaceae cells in pasteurized milk for $7.5 \mathrm{~h}$ of total testing time. Moreover, we demonstrated that the presence of a high load of heat-killed Enterobacteriaceae cells in milk did not produce false-positive results. The use of our PMA-DqPCR enables the specific and successful amplification of viable Enterobacteriaceae bacteria even in the pasteurized milk matrices corresponding to $2 \mathrm{~mL}$ of milk PCR inhibitors, using 20 $\mathrm{mL}$ of a sample volume to collect the target viable cells at the highest possible level. This report is the first to demonstrate the specific and robust detection of viable Enterobacteriaceae cells at a low concentration, following the guidelines from the United States and European Union.

\section{ACKNOWLEDGMENTS}

We thank G\&G Science Co. Ltd. (Fukushima, Japan) for the development of the primer pair designed to specifically detect Enterobacteriaceae cells.

\section{REFERENCES}

Bickley, J., J. K. Short, D. G. McDowell, and H. C. Parkes. 1996. Polymerase chain reaction (PCR) detection of Listeria monocytogenes in diluted milk and reversal of PCR inhibition caused by calcium ions. Lett. Appl. Microbiol. 22:153-158.

Cai, H. Y., P. Bell-Rogers, L. Parker, and J. F. Prescott. 2005. Development of real-time PCR for detecting of Mycoplasma bovis in bovine milk and lung samples. J. Vet. Diagn. Invest. 17:537-545.

Chang, B., K. Sugiyama, T. Taguri, J. Amemura-Maekawa, F. Kura, and H. Watanabe. 2009. Specific detection of viable Legionella cells by combined use of photoactivated ethidium monoazide and PCR/ real-time PCR. Appl. Environ. Microbiol. 75:147-153.

Chang, B., T. Taguri, K. Sugiyama, J. Amemura-Maekawa, F. Kura, and H. Watanabe. 2010. Comparison of ethidium monoazide and propidium monoazide for the selective detection of viable Legionella Cells. Jpn. J. Infect. Dis. 63:119-123.

Cooray, K. J., T. Nishibori, H. Xiong, T. Matsuyama, M. Fujita, and M. Mitsuyama. 1994. Detection of multiple virulence-associated genes of Listeria monocytogenes by PCR in artificially contaminated milk samples. Appl. Environ. Microbiol. 60:3023-3026.

Cressier, B., and N. Bissonnette. 2011. Assessment of an extraction protocol to detect the major mastitis-causing pathogens in bovine milk. J. Dairy Sci. 94:2171-2184.

Fode-Vaughan, K. A., J. S. Maki, J. A. Benson, and M. L. P. Collins. 2003. Direct PCR detection of Escherichia coli O157:H7. Lett. Appl. Microbiol. 37:239-243.

Higoshi, H., S. Oshiro, T. Akamine, and T. Taminato. 1977. Bacteriological examination of raw milk particular reference to resazurin test. Sci. Bull. Coll. of Agric. Univ. Ryukyus Okinawa 24:487496. (In Japanese).

Hillerton, J. E., and A. B. Elizabeth. 2004. Quality of the milk supply: European regulations versus practice. Pages 207-214 in National Mastitis Council Annual Meeting Proceedings. National Mastitits Council, Madison, WI.

Kim, C.-H., M. Khan, D. E. Morin, W. L. Hurley, D. N. Tripathy, M. Kehrli Jr., A. O. Oluoch, and I. Kakoma. 2001. Optimization of the PCR for detection of Staphylococcus aureus nuc gene in bovine milk. J. Dairy Sci. 84:74-83.

Luo, J.-F., W.-T. Lin, and Y. Guo. 2010. Method to detect only viable cells in microbial ecology. Appl. Microbiol. Biotechnol. 86:377384 . 
Martín, M. C., N. Martínez, B. del Rio, V. Ladero, M. Fernández, and M. A. Alvarez. 2010. A novel real-time polymerase chain reactionbased method for the detection and quantification of lactose-fermenting Enterobacteriaceae in the dairy and other food industries. J. Dairy Sci. 93:860-867.

McLaughlin, F. 2006. A brief comparison of the United States and European Union standards for fluid dairy production. A term paper for ANR 811, Michigan State University October 2006. Accessed May 9, 2012. http://www.iflr.msu.edu/uploads/files/109/Student\%20Papers/A_Brief_Comparison_of_United_States_and_ European_Union_Standards_for_Fluid_Dairy_Products.pdf.

Meiri-Bendek, I., E. Lipkin, A. Friedmann, G. Leitner, A. Saran, S. Friedmann, and Y. Kashi. 2002. A PCR-based method for the detection of Streptococcus agalactiae in milk. J. Dairy Sci. 85:17171723.

Minami, J., K. Yoshida, T. Soejima, T. Yaeshima, and K. Iwatsuki. 2010. New approach to use ethidium bromide monoazide as an analytical tool. J. Appl. Microbiol. 109:900-909.

Nocker, A., and A. K. Camper. 2009. Novel approaches toward preferential detection of viable cells using nucleic acid amplification techniques. FEMS Microbiol. Lett. 291:137-142.

Nocker, A., C.-Y. Cheung, and A. K. Camper. 2006. Comparison of propidium monoazide with ethidium monoazide for differentiation of live vs. dead bacteria by selective removal of DNA from dead cells. J. Microbiol. Methods 67:310-320.

Pillai, S. R., and B. M. Jayarao. 2002. Application of IS900 PCR for detection of Mycobacterium avium ssp. paratuberculosis directly from raw milk. J. Dairy Sci. 85:1052-1057.

Rudi, K., B. Moen, S. M. Drømtorp, and A. L. Holck. 2005a. Use of ethidium monoazide and PCR in combination for quantification of viable and dead cells in complex samples. Appl. Environ. Microbiol. 71:1018-1024.

Rudi, K., K. Naterstad, S. M. Drømtorp, and H. Holo. 2005b. Detection of viable and dead Listeria monocytogenes on Gouda-like cheeses by real-time PCR. Lett. Appl. Microbiol. 40:301-306.

Soejima, T., K. Iida, T. Qin, H. Taniai, M. Seki, A. Takade, and S. Yoshida. 2007. Photoactivated ethidium monoazide directly cleaves bacterial DNA and is applied to PCR for discrimination of live and dead bacteria. Microbiol. Immunol. 51:763-775.

Soejima, T., K. Iida, T. Qin, H. Taniai, M. Seki, and S. Yoshida. 2008. Method to detect only live bacteria during PCR amplification. J. Clin. Microbiol. 46:2305-2313.

Soejima, T., K. Iida, T. Qin, H. Taniai, and S. Yoshida. 2009. Discrimination of live, anti-tuberculosis agent-injured, and dead $M y$ cobacterium tuberculosis using flow cytometry. FEMS Microbiol. Lett. 294:74-81.

Soejima, T., F. Schlitt-Dittrich, and S. Yoshida. 2011a. Polymerase chain reaction amplification length-dependent ethidium monoazide suppression power for heat-killed cells of Enterobacteriaceae. Anal. Biochem. 418:37-43.

Soejima, T., F. Schlitt-Dittrich, and S. Yoshida. 2011b. Rapid detection of viable bacteria by nested polymerase chain reaction via long DNA amplification after ethidium monoazide treatment. Anal. Biochem. 418:286-294.

Wu, S.-J., and C. I. Kado. 2004. Preparation of milk samples for PCR analysis using a rapid technique. J. Appl. Microbiol. 96:13421346 . 